\title{
INTEGRACIJA KVANTITATIVNE IN KVALITATIVNE METODOLOGIJE V RAZISKAVAH V ZDRAVSTVU: SISTEMATIČNA PREGLEDNA ŠTUDIJA INTEGRATING QUANTITATIVE AND QUALITATIVE METHODOLOGY IN HEALTH SCIENCE RESEARCH: A SYSTEMATIC REVIEW \\ Joca Zurc'
}

Prispelo: 8. 3. 2012 - Sprejeto: 17. 9. 2012

Pregledni znanstveni članek UDK 001.8:614

\section{Izvleček}

Izhodišča: Priljubljenost integracije kvantitativne in kvalitativne metodologije $v$ isti raziskavi je neverjetno narasla $v$ zadnjih letih. Nimamo pa veliko podatkov o uspešnosti njihove uporabe $v$ raziskovalni praksi na področju zdravstva. Namen te raziskave je bil analizirati področja, osrednje raziskovalne tematike, vrste raziskovalnih načrtov, uspešnost uporabe in nadaljnja odprta vprašanja integracije metod $v$ raziskavah $v$ zdravstvu.

Metode: Raziskava temelji na sistematični pregledni študiji 25 znanstvenih člankov s področja zdravstva, ki so pri svojem raziskovanju uporabili integracijo metod. Vključitvena merila: izvirni znanstveni članek z uporabo in evalvacijo integracije metod, objavljen v obdobju julij 2006-julij 2011 v reviji z recenzijo, ki je vključena $v$ mednarodne baze podatkov: WebSurvey Methodology, CINAHL, MEDLINE in PubMed.

Rezultati: Vseh 25 analiziranih raziskav je potrdilo uspešnost uporabe integracije metod $v$ raziskavah $v$ zdravstvu. Uporaba integracije metod je najpogostejša na področju zdravstvene nege (32\%) in promocije zdravja (28\%). Prevladuje zaporedni način izvedbe kvantitativne in kvalitativne faze raziskave (64,3\%), pri čemer je prva faza v večini primerov dominantna $(71,4 \%)$. Razmerje med kvantitativnim $(57,2 \%)$ in kvalitativnim $(42,8 \%)$ prioritetnim pristopom je uravnoteženo. Najpogosteje uporabljeni nameni integracije metod $v$ raziskavah $v$ zdravstvu so komplementarnost $(57,1 \%)$, triangulacija $(28,6 \%)$ in ekspanzija $(14,3 \%)$.

Zaključki: Dobljene ugotovitve potrjujejo uporabnost integracije metod pri raziskovanju kompleksnih in manj raziskanih problematik $v$ zdravstvu ter izkazujejo potrebe po nadaljnjih raziskovanjih, kot so: konceptualizacija integracije metod $v$ posameznih disciplinah zdravstvenih ved, razvoj meril in standardov ocenjevanja kakovosti raziskav $z$ integracijo metod ter razširitev uvedbe integracije metod $v$ klinično prakso kot podpore pri razvoju na dokazih podprte prakse.

Ključne besede: integracija metod, raziskave $v$ zdravstvu, metodološki kontinuum, prąatizem, raziskovalni načrti, evalvacija, sistematični pregled

Review article UDC 001.8:614

\section{Abstract}

Background: The popularity of integrating quantitative and qualitative methodologies in the same research has grown incredibly in recent years. There is a lack of evidence about the efficiency of mixed methods use in health sciences research practice. The purpose of this study was to analyse the areas, main research themes, mixed methods research design typologies and efficiency of implementation and further open questions regarding mixed methods in health sciences.

Methods: A systematic review was made on a sample of 25 scientific articles of health sciences that stated mixed methods use in research. Inclusion criteria: original scientific article with applying and evaluating of mixed methods, 
published during the period July 2006 - July 2011 in a peer reviewed journal, included in international databases: WebSurvey Methodology, CINAHL, MEDLINE and PubMed.

Results: All 25 studies provided effectiveness of mixed methods use in health science research practice. Mixed methods are the most popular in nursing (32\%) and health promotion (28\%). Sequential mixed methods research design is prevalent (64.3\%), with the first research phase in priority (71.4\%). The relation between quantitative (57.2\%) and qualitative (42.8\%) priority approach is balanced. Complementarity (57.1\%), triangulation (28.6\%) and expansion (14.3\%) are the most common research purposes for using mixed methods in health sciences.

Conclusions: The presented findings confirmed mixed methods applicability for the complex and less studied research problems in health sciences. Conceptualisation of mixed methods in different disciplines of health sciences, development of quality criteria and standards for mixed methods research assessment and expansion of mixed methods in clinical practice as support in evidence based practice development appeared as the most important research questions of mixed methods in health sciences that should be addressed in the future studies.

Key words: mixed methods, health science research, methodological continuum, prąatism, research designs, evaluation, systematic review

\section{UVOD}

Integracija metod se kot tretja raziskovalna skupina v znanosti (1), tretji metodološki moment (2), tretja raziskovalna pot (3) ali tretja raziskovalna paradia (4) nahaja na večrazsežnostnem kontinuumu med kvantitativnim in kvalitativnim raziskovalnim pristopom. Predstavlja novo dimenzijo v znanosti, ki jo je spodbudila dihotomija med kvalitativno in kvantitativno tradicijo $\mathrm{v}$ zadnjih 20 letih (1). Cilj integracije metod ni zamenjati kvantitativni ali kvalitativni pristop, ampak okrepiti moči in zmanjšati šibkosti obeh v eni skupni raziskavi (4). Niglas (5) piše o celostnem multidimenzionalnem kontinuumu raziskovalne metodologije [angl. Integrated Multidimensional Continuum of Research Methodology], kjer integracija metod pokriva široko področje točk na sredini med levo, skrajno kvantitativnim in desno, skrajno kvalitativnim pristopom. Metodološki kontinuum pomeni premik od dveh temeljnih dihotomnih paradigem oz. svetovnih nazorov k fleksibilnemu paradiatskemu kontinuumu. Gre za celostni pristop k raziskovanju, ki poudarja hkrati ustvarjanje nove teorije in preverjanje obstoječe teorije kot skupni namen kvalitativnega in kvantitativnega raziskovanja. Johnson, Onwuegbuzie in Turner (6) opredeljujejo raziskave z integracijo metod kot intelektualne in praktične sinteze kvantitativnega in kvalitativnega raziskovanja. Izpostavljajo, da integracija metod prepoznava pomen tradicionalne kvantitativne in kvalitativne metodologije, vendar hkrati ponuja tretjo paradigmatsko opcijo za zagotavljanje kar najbolj informativnih, izpopolnjenih, uravnoteženih in uporabnih ugotovitev raziskave. Tako integracija metod spodbuja oblikovanje novih raziskovalnih vprašanj in hkrati zagotavlja poti za odgovore na ta vprašanja.

Teddlie in Tashakkori (1) opozarjata, da se je raziskava $\mathrm{z}$ integracijo metod do zdaj poimenovala $\mathrm{z}$ različnimi nekonsistentnimi terminološkimi izrazi. Ena izmed osrednjih zamenjav je bila s terminom »večmetodni pristop « [angl. multimethod design], za katerega so, kot navajata avtorja, značilne različne opredelitve, in sicer od uporabe vsaj dveh kvantitativnih metod $v$ isti kvantitativni raziskavi ali vsaj dveh kvalitativnih metod $v$ isti kvalitativni raziskavi kot tudi do uporabe kvantitativne in kvalitativne metodologije skupaj $v$ isti raziskavi, vendar na način dveh razločno ločenih delov. Pri integraciji metod pa gre za način raziskovanja, s katerim raziskovalci integrirajo ali združujejo kvantitativne in kvalitativne raziskovalne tehnike, metode, pristope, koncepte ali jezik $v$ eno skupno raziskavo (4). Večmetodni pristop ima ključno vlogo pri razvoju integracije metod, vendar je temeljna razlika med pristopoma danes $\vee$ tem, da integracija metod presega enostavno zbiranje različnih vrst podatkov in vsebuje koncept združevanja ali integriranja kvalitativnih in kvantitativnih podatkov (7).

Johnson, Onwuegbuzie in Turner (6) so na osnovi analize 19 različnih definicij strokovnjakov na področju raziskav $z$ integracijo metod oblikovali definicijo integracije metod, $v$ kateri je raziskava $z$ integracijo metod poimenovana kot samostojna vrsta raziskave, v kateri raziskovalec ali skupina raziskovalcev združuje elemente kvantitativnega in kvalitativnega raziskovalnega pristopa $v$ pogledih na raziskovalni problem, zbiranju in analizi podatkov ter zaključevanju ugotovitev z namenom širjenja in poglobitve razumevanja ter podkrepitve raziskovalnih ugotovitev. Raziskava z integracijo metod tako vedno vključuje integracijo ali združevanje kvantitativne in kvalitativne metodologije $\checkmark$ vseh fazah znotraj iste raziskave.

Uporaba integracije metod omogoča raziskovalcem opredeliti bolj holistično sliko problema, ki ga raziskujejo (8). Zlasti je zato primerna za uporabo v zdravstvenih 
vedah, zaradi kompleksnosti proučevanih raziskovalnih problemov (9). Dozdajšnje raziskave so pokazale uporabnost integracije metod pri raziskovanju specifičnih subpopulacij (npr. podeželje, nosečnice, manjšine, mladi odvisniki) (10-12), tematik s področja življenjskega sloga in zdravja (promocija zdravja, življenjski slog, socialna politika) (13-16) in spletnega raziskovanja, ki kot nova metodologija spodbuja integracijo metod $z$ namenom povečevanja števila udeležencev $v$ raziskavi in zmanjševanja stroškov raziskovanja $(8,17-22)$. Integracija metod je postala pomemben način razvoja znanosti. Vendar raziskovalci opozarjajo, da različni načini zbiranja podatkov povzročajo tudi tveganja za pojav rezultatov pomanjkljive primerljivosti (23). Plano Clark s sodelavci (24) navaja, da je uspešnost uporabe integracije metod $v$ raziskavi odvisna predvsem od raziskovalčevega razumevanja in poznavanja različnih raziskovalnih načrtov, ki spremljajo in definirajo ta raziskovalni pristop.

Obstajajo različne tipologije raziskovalnih načrtov $v$ raziskavah $z$ integracijo metod, ki opredeljujejo postopke zbiranja, analiziranja, interpretacije in poročanja podatkov $v$ raziskavah $\mathrm{z}$ integracijo kvantitativne in kvalitativne metodologije (25). Tipologije se razvijajo na osnovi preglednih sistematičnih študij vse od začetkov razvoja integracije metod. Njihov namen je pomagati raziskovalcem pri odločitvi, kako naj pristopijo $\mathrm{k}$ načrtovanju raziskave $\mathrm{z}$ integracijo metod in kako naj v množici najrazličnejših možnosti izberejo tiste, ki bodo najboljše odgovorile na zastavljene cilje raziskave. Tipologije omogočajo tudi vzpostavitev terminologije, organizacijske strukture in legitimacije področja integracije metod. Tipologije se uporabljajo tudi kot pedagoško didaktično orodje za učenje načrtovanja raziskave $z$ integracijo metod pri študentih (1). Izpostavljamo štiri uveljavljene tipologije integracije metod, ki so nastale med drugim tudi na osnovi izvedenih raziskav $v$ zdravstvu, ter jih $v$ nadaljevanju uporabljamo kot analitično orodje sistematične pregledne študije (Tabela 3).

Tipologija Morgan (26) temelji na modelu prioriteta zaporedje, s katerima tvori štiri temeljne raziskovalne načrte integracije metod: predhodna kvalitativna metoda $v$ kvantitativni raziskavi [angl. qualitative preliminary] (qual-QUAN), predhodna kvantitativna metoda $v$ kvalitativni raziskavi [angl. quantitative preliminary] (quan-QUAL), nadaljevalna kvalitativna metoda $v$ kvantitativni raziskavi [angl. qualitative followup] (QUAN-qual) in nadaljevalna kvantitativna metoda $\checkmark$ kvalitativni raziskavi [angl. quantitative follow-up] (QUAL-quan). To tipologijo sta nadgradila Teddlie in Tashakkori (1), ki sta postavila pet skupin raziskovalnih načrtov integracije metod, in sicer sočasni raziskovalni načrt [angl. parallel mixed design], ki odgovarja na sorodne vidike krovnega raziskovalnega vprašanja, zaporedni raziskovalni načrt [angl. sequential mixed design], pri katerem zaključki prve faze usmerjajo izvedbo druge faze, pretvorni raziskovalni načrt [angl. conversion mixed design], pri katerem je ena vrsta podatkov spremenjena (kvantificirana ali kvalitizirana), raziskovalni načrt $\mathrm{z}$ integracijo metod na različnih ravneh proučevanja [angl. multilevel mixed design] ter $v$ celoti integrirani raziskovalni načrt [angl. fully integrated mixed design], pri katerem se kvalitativni in kvantitativni pristop združujeta v vseh fazah raziskave; v vsaki fazi en pristop vpliva na oblikovanje drugega in na pojav več načinov implementacije integracije.

Tipologija Greene $(27,28)$ se osredotoča na namen integracije kvalitativnega in kvantitativnega raziskovalnega pristopa, ki izhaja iz raziskovalnega problema in raziskovalnih vprašanj posamezne raziskave. Tipologija vključuje pet temeljnih namenov integracije metod: triangulacija [angl. triangulation], pri kateri so uporabljene različne metode, ki vse merijo isti pojav, komplementarnost [angl. complementarity], pri katerem rezultati ene metode služijo za povečanje, poglobitev in razširitev ugotovitev, pridobljenih z drugo metodo, razvoj [angl. development], pri katerem so rezultati ene metode uporabljeni za razvoj druge metode, iniciacija [angl. initiation], ki temelji na namenu vpeljevanja paradoksov, nasprotij in razhajanj, ki vodijo v odpiranje novih pogledov, perspektiv in razumevanj, ter ekspanzija [angl. expansion], katere namen je razširitev proučevanja raziskovalnega problema na različne nize raziskovalnih žarišč.

Creswell in Plano Clark (25) sta na osnovi 12 različnih tipologij raziskovalnih načrtov $v$ raziskavah $z$ integracijo metod, ki so se razvili in uveljavili v raziskovalni praksi zdravstva in izobraževanja ter socioloških, vedenjskih in evalvacijskih študij, oblikovala funkcionalno tipologijo 4 osrednjih vrst raziskovalnih načrtov integracije metod, in sicer triangulacija [angl. triangulation design], ugnezden raziskovalni načrt [angl. embedded design], pojasnjevalni raziskovalni načrt [angl. explanatory design] in eksploratorni raziskovalni načrt [angl. exploratory design]. Novo tipologijo sta avtorja utemeljila na osnovi velikih podobnosti med proučevanimi 12 tipologijami, ki pa uporabljajo različna poimenovanja in poudarjajo različne strani integracije metod.

Na osnovi navedenega je bil namen empirične raziskave s sistematičnim pregledom objavljenih izsledkov raziskav na področju zdravstva $v$ zadnjih petih letih ugotoviti področja in osrednje raziskovalne tematike, vrste uporabljenih raziskovalnih načrtov, uspešnost 
uporabe in nadaljnja odprta vprašanja integracije metod $\checkmark$ raziskavah $v$ mednarodnem raziskovalnem prostoru na področju zdravstva ter na tej osnovi poudariti potrebe po nadaljnjih raziskovalnih izzivih proučevanja in razvoja integracije metod $v$ zdravstvu. Raziskovalna vprašanja, na katera smo želeli odgovoriti z empirično kvalitativno raziskavo, so bila:

- V katerih raziskovalnih disciplinah $v$ zdravstvenih vedah se pri raziskovanju pojavlja integracija metod in v kakšnem obsegu v obdobju zadnjih petih let?

- Katere osrednje raziskovalne tematike oziroma raziskovalni cilji na področju zdravstva se raziskujejo $z$ integracijo metod $v$ obdobju zadnjih petih let?

- Katere vrste raziskovalnih načrtov integracije kvantitativne in kvalitativne metodologije se pojavljajo $v$ analiziranih raziskavah glede na vrsto implementacije integracije metod $v$ raziskovalnem procesu (1), prioriteto in zaporedje kvantitativnega in kvalitativnega metodoloških pristopa (26), namen uporabe integracije metod, ki izhaja iz namena in raziskovalnih vprašanj posamezne raziskave $(27,28)$, in glede na funkcionalno tipologijo štirih osrednjih vrst raziskovalnih načrtov integracije metod (25)?

- Kakšni so evalvacijski izsledki raziskav, ki so uporabile integracijo metod $v$ zadnjih petih letih, ali podpirajo ali spodbijajo uporabo integracije metod $v$ raziskovanju na področju zdravstva?

- Na katera nadaljnja odprta raziskovalna vprašanja uporabe integracije metod $v$ mednarodnem raziskovalnem prostoru na področju zdravstva kažejo ugotovitve dozdajšnjih raziskav v obdobju zadnjih petih let ter katere so osrednje potrebe po nadaljnjih raziskovalnih izzivih proučevanja in razvoja integracije metod $v$ raziskovanju $v$ zdravstvu?

\section{METODE}

Sistematični pregled raziskav $z$ integracijo kvantitativne in kvalitativne metodologije temelji na pregledu izvirnih znanstvenih prispevkov $v$ zadnjih petih letih (julij 2006-julij 2011), ki so bili objavljeni v javno dostopnih mednarodnih bazah podatkov s področja zdravstva, medicine in raziskovalne metodologije.
Podatke smo iskali $v$ elektronskih bazah podatkov prispevkov $v$ znanstvenih revijah s področja zdravstva in metodologije: WebSurvey Methodology, EBESCOhost (CINAHL, MEDLINE) in PubMed s ključnimi iskalnimi besedami $v$ angleškem jeziku: mixed methods, research methodology, research method, statistics research, mixed methods research, method evaluation, mixed methods evaluation, systematic review, health science, research design, evaluation. $V$ vseh bazah podatkov smo uporabili napredno iskanje po naslovu, ključnih besedah in po celotnem besedilu prispevka ter Boolov logični operator »and « med dvema in več ključnimi besedami. Obdobje pregleda literature je potekalo od julija 2011 do septembra 2011. V pregledno sistematično analizo so bile vključene raziskave, ki so izpolnjevale naslednja vključitvena merila:

- izvirni znanstveni članek [angl. journal article, research],

- objava prispevka v zadnjih petih letih (julij 2006-julij 2011),

- revija z recenzijo,

- dostopno polno besedilo članka,

- angleški jezik,

- raziskava s področja zdravstva (vsaj ena raziskovalna disciplina $v$ zdravstvu),

- razvidnost iz opisa ciljev, metod dela in rezultatov, da je raziskava vključevala integracijo metod,

- evalvacija uporabljene integracije metod $v$ raziskavi s področja zdravstva.

Izključitvena merila:

- raziskave, ki niso izpolnjevale navedenih vključitvenih meril (na primer raziskave s sorodnih in interdisciplinarnih področij, kot so osebe s posebnimi potrebami, socialno delo, kakovost raziskovanja),

- uporaba samo enega pristopa v raziskavi - samo kvalitativnega ali samo kvantitativnega,

- raziskave s področja zdravstva z integracijo metod, ki pa niso vključevale evalvacije uporabljene integracije kvantitativne in kvalitativne metodologije,

- vse objave zunaj kategorije izvirnih in preglednih znanstvenih člankov (na primer predlogi raziskav, uvodniki, pregledne študije brez strukture raziskovalnega prispevka, prispevki na konferencah itn.). 
Tabela 1. Potek iskanja raziskav $z$ integracijo metod $v$ izbranih spletnih bazah objav.

Table 1. The process of article searching in selected online publication data bases.

\begin{tabular}{|c|c|c|c|c|c|c|}
\hline \multirow{2}{*}{$\begin{array}{l}\text { Ključne besede/ } \\
\text { Key words }\end{array}$} & \multicolumn{2}{|l|}{ WebSM } & \multicolumn{2}{|c|}{ EBESCOhost } & \multicolumn{2}{|l|}{ PubMed } \\
\hline & $\begin{array}{l}\text { zadetki/ } \\
\text { results }\end{array}$ & $\begin{array}{l}\text { izbran/ } \\
\text { selected }\end{array}$ & $\begin{array}{l}\text { zadetki/ } \\
\text { results }\end{array}$ & $\begin{array}{l}\text { izbrani/ } \\
\text { selected }\end{array}$ & $\begin{array}{l}\text { zadetki/ } \\
\text { results }\end{array}$ & $\begin{array}{l}\text { izbrani/ } \\
\text { selec-ted }\end{array}$ \\
\hline mixed methods & 76 & 5 & 413 & 9 & 3.667 & 2 \\
\hline $\begin{array}{l}\text { mixed methods, research } \\
\text { methodology }\end{array}$ & 0 & 0 & 50 & 7 & 743 & 2 \\
\hline $\begin{array}{l}\text { mixed methods, research } \\
\text { method }\end{array}$ & 0 & 0 & 42 & 2 & 993 & 2 \\
\hline $\begin{array}{l}\text { mixed methods, statistics } \\
\text { research }\end{array}$ & 0 & 0 & 7 & 2 & 409 & 2 \\
\hline $\begin{array}{l}\text { mixed methods, research } \\
\text { methodology, research } \\
\text { method, statistics research }\end{array}$ & 0 & 0 & 0 & 0 & 116 & 2 \\
\hline $\begin{array}{l}\text { mixed methods, health } \\
\text { science }\end{array}$ & 0 & 0 & 9 & 4 & 25 & 2 \\
\hline $\begin{array}{l}\text { mixed methods research, } \\
\text { health science, method } \\
\text { evaluation }\end{array}$ & 0 & 0 & 13 & 2 & 1 & 0 \\
\hline $\begin{array}{l}\text { mixed methods evaluation, } \\
\text { health science, systematic } \\
\text { review }\end{array}$ & 0 & 0 & 7 & 3 & 3 & 0 \\
\hline $\begin{array}{l}\text { mixed methods research, } \\
\text { health science, research } \\
\text { design, evaluation }\end{array}$ & 0 & 0 & 49 & 8 & 1 & 0 \\
\hline $\begin{array}{l}\text { Skupno število prispevkov/ } \\
\text { Total number of articles }\end{array}$ & 76 & 5 & 540 & 37 & 5.958 & 12 \\
\hline
\end{tabular}

Z enajstimi ključnimi besedami $v$ devetih iskalnih kombinacijah in treh osrednjih iskalnikih elektronskih baz podatkov znanstvenih prispevkov s področja zdravstva in metodologije smo dobili skupaj 6.574 zadetkov, ki so ustrezali iskalnim merilom naprednega iskanja (Tabela 1). Največ zadetkov je dala spletna baza podatkov PubMed ( $n=5.958)$, vendar je bilo po pregledu naslovov in izvlečkov prispevkov ugotovljeno, da glavnina zadetkov ne ustreza vključitvenim merilom. Osrednji razlog za to je bila presplošna izbira ključnih besed (zlasti v prvih štirih kombinacijah), ki so se nanašale samo na raziskovalno metodologijo in so uvrstile v zadetke raziskave s področij zunaj zdravstvenih ved, večina prispevkov tudi ni bila prosto dostopna s celotnim besedilom, kar je predstavljalo enega izmed vključitvenih meril in pogoj za nadaljnjo sistematično analizo. $V$ zadnjih štirih iskalnih kombinacijah ključnih besed, ki so bile natančneje specificirane glede na raziskovalna vprašanja in vezane na področje zdravstva, se je iskanje $v$ bazi PubMed vidno izboljšalo, kar kaže število zadetkov. Podoben proces je viden tudi pri iskanju v bazi EBESCOhost, kjer so ožje specificirane in $z$ raziskovalno tematiko povezane ključne besede dale vsebinsko ustreznejše rezultate. Najmanjše število zadetkov je bilo dobljeno $v$ bazi podatkov metodoloških raziskav WebSurvey Methodology, kar je pričakovano glede na velikost baze $v$ primerjavi $s$ preostalima in iskanje ozko specializiranih raziskav, ki obravnavajo metodološka vprašanja integracije metod pri raziskovanju zdravstvenih ved.

Po pregledu izvlečkov, naslovov in predmetnih oznak prispevkov je vključitvenim merilom ustrezalo 54 zadetkov, katerih objavljena besedila so bila natančno prebrana in pregledana $v$ celoti. Po pregledu teh celotnih besedil $z$ vidika vseh vključitvenih in tudi izključitvenih meril ter izločitvi podvojenih zadetkov 
se je $v$ končni izbor sistematične pregledne analize uvrstilo 25 raziskav (46,3-odstotna realizacija). Najpogostejše vključitveno merilo, ki ga ni izpolnjevala večina od $29 v$ analizo neuvrščenih raziskav, je bila evalvacija uporabljene integracije kvantitativne in kvalitativne metodologije. Tovrstne raziskave so za namen specifičnega raziskovalnega problema $s$ področja zdravstva uporabile integracijo metod, vendar uporabljene metodologije niso evalvirale.

\section{REZULTATI}

Tabela 2. Raziskovalne discipline $v$ zdravstvu in raziskovalni problemi/cilji izbranih raziskav $z$ integracijo metod $v$ zadnjih petih letih.

Table 2. Mixed methods in analyzed studies relating to health science research areas and research purposes/ aims.

\begin{tabular}{|c|c|c|}
\hline $\begin{array}{l}\text { Raziskaval } \\
\text { Study }\end{array}$ & $\begin{array}{l}\text { Disciplina v } \\
\text { zdravstvu/ } \\
\text { Health } \\
\text { science area }\end{array}$ & $\begin{array}{l}\text { Raziskovalna tematika/cilji/ } \\
\text { Research topics/aims }\end{array}$ \\
\hline $\begin{array}{l}\text { Östlund et al., } \\
2011(9)\end{array}$ & $\begin{array}{l}\text { zdravstvo - } \\
\text { vsa področja }\end{array}$ & $\begin{array}{l}\text { raziskati analitične pristope (npr. sočasni, zaporedni), ki se uporabljajo } \\
\text { v raziskavah z integracijo metod v zdravstvu, in ponazoriti uporabo } \\
\text { triangulacije kot metodološke prispodobe za povezavo med kvalitativnimi in } \\
\text { kvantitativnimi ugotovitvami, pregledna sistematična študija za obdobje od } \\
1999 \text { do } 2009\end{array}$ \\
\hline $\begin{array}{l}\text { Landsverk et } \\
\text { al., } 2011 \text { (29) }\end{array}$ & $\begin{array}{l}\text { promocija } \\
\text { zdravja }\end{array}$ & $\begin{array}{l}\text { razvoj metodoloških pristopov za raziskovanje implementacijskih strategij } \\
\text { intervencij in njihovih evalvacij, strukturirani pregled literature na področju } \\
\text { duševnega zdravja otrok }\end{array}$ \\
\hline $\begin{array}{l}\text { Baker et al., } \\
2010(30)\end{array}$ & $\begin{array}{l}\text { promocija } \\
\text { zdravja }\end{array}$ & $\begin{array}{l}\text { evalvirati učinkovitost na procesu temelječe prevajalske metode anketnega } \\
\text { instrumenta s področja zdravja }\end{array}$ \\
\hline $\begin{array}{l}\text { Mortenson, } \\
\text { Oliffe, } 2009 \\
\text { (31) }\end{array}$ & $\begin{array}{l}\text { delovna } \\
\text { terapija }\end{array}$ & $\begin{array}{l}\text { analizirati raznolike definicije in načine uporabe integracije metod, pregledna } \\
\text { študija za obdobje } 2000-2005 \text { v } 9 \text { revijah s področja delovne terapije }\end{array}$ \\
\hline $\begin{array}{l}\text { Dunning, } \\
\text { LeMasters, } \\
2009(32)\end{array}$ & $\begin{array}{l}\text { delovna } \\
\text { terapija }\end{array}$ & $\begin{array}{l}\text { proučiti različne načine zbiranja podatkov na področju delovne terapije: } \\
\text { telefonsko, spletno in poštno anketno raziskovanje o padcih na delovnem } \\
\text { mestu pri nosečnicah z namenom ugotavljanja pristranskosti, zanesljivosti in } \\
\text { manjkajočih podatkov }\end{array}$ \\
\hline $\begin{array}{l}\text { Nigg et al., } \\
2009 \text { (33) }\end{array}$ & $\begin{array}{l}\text { promocija } \\
\text { zdravja }\end{array}$ & $\begin{array}{l}\text { testiranje različnih metodoloških pristopov zbiranja podatkov (telefon, telefon } \\
\text { - splet) na primeru gibalne aktivnosti in uživanja sadja/zelenjave na vzorcu } \\
\text { odraslih }\end{array}$ \\
\hline $\begin{array}{l}\text { Vatne, } \\
\text { Fagermoen, } \\
2008(34)\end{array}$ & $\begin{array}{l}\text { zdravstvena } \\
\text { nega }\end{array}$ & $\begin{array}{l}\text { predstaviti novo kakovostno raziskovalno strategijo integracije metod zbiranja } \\
\text { in obdelave podatkov, ki je usmerjena na raziskovalni problem in predstavlja } \\
\text { eno izmed metod triangulacije }\end{array}$ \\
\hline $\begin{array}{l}\text { Bushy, } 2008 \\
(13)\end{array}$ & $\begin{array}{l}\text { zdravstvena } \\
\text { nega }\end{array}$ & $\begin{array}{l}\text { obravnava metodoloških izzivov pri raziskovanju zdravstvene nege na } \\
\text { podeželju z vidika kulturnih in etničnih značilnosti prebivalstva na podeželju }\end{array}$ \\
\hline $\begin{array}{l}\text { Hopson, } \\
\text { Steiker, } 2008 \\
(12)\end{array}$ & $\begin{array}{l}\text { promocija } \\
\text { zdravja }\end{array}$ & $\begin{array}{l}\text { proučiti inovativni metodološki pristop za evalvacijo intervencijskega } \\
\text { programa pri mladih z visokim tveganjem za pojav zasvojenosti v } \\
\text { alternativnih šolah }\end{array}$ \\
\hline $\begin{array}{l}\text { Joubert, Lee, } \\
2007 \text { (35) }\end{array}$ & $\begin{array}{l}\text { informacijske } \\
\text { tehnologije v } \\
\text { zdravstvu }\end{array}$ & $\begin{array}{l}\text { opisati način povezovanja med kvantitativnimi in kvalitativnimi podatki o } \\
\text { kakovosti storitev akademskih knjižnic s področja zdravstvenih ved glede na } \\
\text { ponudbo storitev in zadovoljstvo uporabnikov }\end{array}$ \\
\hline
\end{tabular}




\begin{tabular}{|c|c|c|}
\hline $\begin{array}{l}\text { Andrew, } \\
\text { Halcomb, } 2006 \\
(10)\end{array}$ & $\begin{array}{l}\text { zdravstvena } \\
\text { nega }\end{array}$ & $\begin{array}{l}\text { oris uporabnosti integracije metod pri raziskovanju patronažnega zdravstva } \\
\text { in prikaz povečanja vrednosti pridobljenih podatkov s tem metodološkim } \\
\text { pristopom }\end{array}$ \\
\hline $\begin{array}{l}\text { McCabe et al., } \\
2006(36)\end{array}$ & $\begin{array}{l}\text { promocija } \\
\text { zdravja }\end{array}$ & $\begin{array}{l}\text { proučiti učinke različnih načinov zbiranja podatkov (splet in pošta) } v \\
\text { anketnem raziskovanju o uživanju alkohola na osmih ameriških visokih šolah }\end{array}$ \\
\hline $\begin{array}{l}\text { Smyth, Allen, } \\
2011 \text { (37) }\end{array}$ & $\begin{array}{l}\text { zdravstvena } \\
\text { nega }\end{array}$ & $\begin{array}{l}\text { raziskati in opisati, kako medicinske sestre opredeljujejo duhovnost in kako } \\
\text { duhovno oskrbo vključujejo v svojo klinično prakso }\end{array}$ \\
\hline $\begin{array}{l}\text { Ploeg et al., } \\
2010 \text { (38) }\end{array}$ & $\begin{array}{l}\text { zdravstvena } \\
\text { nega }\end{array}$ & $\begin{array}{l}\text { ugotoviti, kako reprezentativni predstavniki klinične prakse zdravstvene nege } \\
\text { vplivajo na širjenje priporočil »Smernice za najboljšo prakso» }\end{array}$ \\
\hline $\begin{array}{l}\text { Hawkes et al., } \\
2010 \text { (39) }\end{array}$ & $\begin{array}{l}\text { zdravstvena } \\
\text { nega }\end{array}$ & $\begin{array}{l}\text { raziskati razvoj, implementacijo in rezultate uspešnosti izvajanja kliničnih } \\
\text { smernic za medicinske sestre pri bolnikih po posegu vsaditve obvoda } \\
\text { koronarne arterije }\end{array}$ \\
\hline $\begin{array}{l}\text { Beckwith et al., } \\
2010(40)\end{array}$ & $\begin{array}{l}\text { zdravstvena } \\
\text { nega }\end{array}$ & $\begin{array}{l}\text { proučiti razumevanje ocenjevanja bolnikov, ki ga izvajajo medicinske sestre, } \\
\text { sistematična pregledna študija z integracijo metod za obdobje od } 1990 \text { do } \\
2005\end{array}$ \\
\hline $\begin{array}{l}\text { Rivard et al., } \\
2010 \text { (41) }\end{array}$ & fizioterapija & $\begin{array}{l}\text { opis aktivnosti posredovalcev znanja za uporabo raziskovalnih dokazov v } \\
\text { klinični praksi pediatrične fizikalne terapije ter prikaz njihovih pogledov o } \\
\text { pomenu vloge in izkušnjah s posredovanjem }\end{array}$ \\
\hline $\begin{array}{l}\text { Colarossi et al., } \\
2010(42)\end{array}$ & javno zdravje & $\begin{array}{l}\text { proučiti mnenja zdravstvenega osebja v centrih za načrtovanje družine, ki } \\
\text { imajo izdelan protokol za ugotavljanje oz. presejanje nasilja med intimnima } \\
\text { partnerjema z vidika njihovih stališč, dojemanja ovir in usposobljenosti za } \\
\text { izvajanje tovrstnih presejalnih programov }\end{array}$ \\
\hline $\begin{array}{l}\text { Blakely et al., } \\
2010 \text { (43) }\end{array}$ & $\begin{array}{l}\text { promocija } \\
\text { zdravja }\end{array}$ & $\begin{array}{l}\text { proučiti perspektive edukatorjev zdravja o uporabi didaktičnih iger v } \\
\text { zdravstvu }\end{array}$ \\
\hline $\begin{array}{l}\text { Schreiber et al., } \\
2009(44)\end{array}$ & fizioterapija & $\begin{array}{l}\text { ugotoviti učinkovitost programa, na dokazih podprta praksa v fizioterapiji, ki } \\
\text { temelji na sodelovanju med akademskim in kliničnim okoljem, s poudarkom } \\
\text { na ugotavljanju uporabe raziskovalnih izsledkov pri sprejemanju kliničnih } \\
\text { odločitev }\end{array}$ \\
\hline $\begin{array}{l}\text { Durham et al., } \\
2009(45)\end{array}$ & fizioterapija & $\begin{array}{l}\text { raziskati osredinjenost fizioterapevtov na dajanje povratnih informacij med } \\
\text { obravnavo in pogostnost dajanja povratnih informacij o gibalni izvedbi }\end{array}$ \\
\hline $\begin{array}{l}\text { Schaetti et al., } \\
2009(46)\end{array}$ & javno zdravje & $\begin{array}{l}\text { oblikovati priporočilo za uvedbo rednega cepiva proti koleri z vidika socialno- } \\
\text { ekonomskih in vedenjskih dejavnikov za trajno strategijo preprečevanja } \\
\text { kolere } v \text { Zanzibaru }\end{array}$ \\
\hline $\begin{array}{l}\text { Sverker et al., } \\
2009(47)\end{array}$ & dietetika & $\begin{array}{l}\text { raziskati problematike obolenja s celiakijo v vsakdanjem življenju pri obolelih } \\
\text { in njihovih svojcih v kontekstu priprave hrane v gospodinjstvu }\end{array}$ \\
\hline $\begin{array}{l}\text { Levett-Jones et } \\
\text { al., } 2008 \text { (48) }\end{array}$ & $\begin{array}{l}\text { zdravstvena } \\
\text { nega }\end{array}$ & $\begin{array}{l}\text { raziskati pripadnost študentov do zdravstvene nege z vidika trajanja } \\
\text { kliničnega usposabljanja }\end{array}$ \\
\hline $\begin{array}{l}\text { Barnes et al., } \\
2008(15)\end{array}$ & $\begin{array}{l}\text { promocija } \\
\text { zdravja }\end{array}$ & $\begin{array}{l}\text { proučiti učinke 12-tedenskega promocijskega programa na kakovost življenja } \\
\text { in zadovoljstvo z življenjem pri odraslih z nizkimi prihodki }\end{array}$ \\
\hline
\end{tabular}


Tabela 1 prikazuje, da je 25 analiziranih študij z integracijo metod izhajalo iz 8 različnih raziskovalnih disciplin zdravstvenih ved. Največ raziskav, ki so izpolnjevale vključitvena merila za analizo z vidika integracije metod, je prihajalo s področij zdravstvene nege (8 raziskav ali $32 \%$ ) in promocije zdravja (7 raziskav ali $28 \%$ ). Tri raziskave so bile s področja fizioterapije, po dve iz delovne terapije in javnega zdravja ter po ena raziskava iz dietetike in informacijskih tehnologij v zdravstvu. Raziskava Östlund s sodelavci (9), ki je s sistematično analizo proučevala pristope $v$ raziskavah $\mathrm{z}$ integracijo metod $\mathrm{v}$ zdravstvu na vzorcu 168 raziskav za obdobje desetih let, pa se ni omejila na posamezne discipline znotraj zdravstvenih ved.

Poglobljena analiza besedil objavljenih prispevkov je pokazala dve osrednji vrsti raziskav, in sicer raziskave, ki $v$ središče raziskovanja postavljajo proučevanje integracije metod $(9,29-34,13,12,35$, $10,36)$, ter raziskave, ki integracijo metod uporabljajo kot metodološko orodje za proučevanje drugih raziskovalnih tematik ter $v$ tem okviru tudi analizirajo in vrednotijo njihovo ustreznost $(37-48,15)$. Razmerje med skupinama je glede na število vključenih raziskav enakovredno, saj se je v analizo uvrstilo 12 temeljnih metodoloških raziskav integracije metod $v$ zdravstvu in 13 aplikativnih raziskav $z$ uporabo in evalvacijo integracije metod $v$ zdravstvu.

Poglobljena analiza besedil je tudi pokazala, da kljub opredelitvi avtorjev $v$ ključnih besedah in teoretičnih izhodiščih, da gre za uporabo ali proučevanje integracije metod, pa nekatere raziskave sodijo na področje proučevanja različnega načina zbiranja podatkov in ne integracije kvantitativne in kvalitativne metodologije. Raziskava Dunning in LeMasters (32) se posveča proučevanju načina zbiranja podatkov 0 padcih na delovnem mestu pri nosečnicah glede na spletno, telefonsko ali pisno kvantitativno anketiranje. Čeprav so avtorji zapisali integracijo metod pod ključne besede, pa so v zaključku poudarili, da gre za pomen integracije različnih načinov zbiranja podatkov z namenom zmanjšanja metodološke pristranskosti in povečanja števila udeležencev na področju raziskav delovne terapije. Podobno velja tudi za raziskavo Nigg s sodelavci (33), ki prikazuje rezultate samo kvantitativne anketne metodologije in raziskuje različne načine zbiranja podatkov o gibalni aktivnosti in uživanju sadja ter zelenjave preko telefona in kombinacije telefon-splet. McCabe s sodelavci (36) prav tako proučuje učinke različnih načinov zbiranja podatkov (splet in pošta) v kvantitativnem anketnem raziskovanju o uživanju alkohola na ameriških visokih šolah. Joubert in Lee (35) $v$ uvodnem delu prispevka predstavita integrirani model kvantitativnih in kvalitativnih merjenj kakovosti knjižničnih storitev in poudarita, da integrirani rezultati omogočajo načrtovalcem akademskih knjižničnih storitev razviti visoko ciljno orientirane in učinkovite knjižnične programe in storitve na področju zdravstvenih ved, objavljeni prispevek pa predstavlja metode dela in rezultate samo kvantitativnega dela študije.

Tabela 3 prikazuje analizo 14 vključenih raziskav z integracijo metod (56\%) glede na vrsto raziskovalnih načrtov po štirih osrednjih tipologijah, in sicer glede na postopek izvedbe kvantitativnega in kvalitativnega dela $\checkmark$ raziskavi (1), prioriteto in zaporedje kvantitativnega in kvalitativnega pristopa (26), namen uporabe integracije metod $(27,28)$ in glede na funkcionalno tipologijo štirih osrednjih raziskovalnih načrtov integracije metod (25). $\mathrm{V}$ analizo tabele 3 ni bilo uvrščenih 11 analiziranih raziskav (44\%), ki so temeljile na sistematičnih pregledih literature $(9,29,31,34,13,10,40)$ ali pa na različnih načinih zbiranja podatkov $(32,33,35,36)$. Te raziskave so vključevale obravnavo in evalvacijo integracije metod, vendar pri svojem proučevanju med metodami dela niso uporabile integracije kvantitativne in kvalitativne metodologije, zato analiza tipologij uporabljenih raziskovalnih načrtov integracije metod ni bila mogoča.

Tabela 3 kaže, da glede na način izvedbe integracije $\checkmark$ raziskavah prevladuje zaporedni raziskovalni načrt $(64,3 \%)$, pri katerem ugotovitve prve raziskovalne faze, ki je kvantitativna ali kvalitativna, usmerjajo izvedbo druge metodološke faze (1). Izvedba posameznih faz poteka kronološko, in sicer se druga faza razvije iz prve in je od nje odvisna. Sočasni raziskovalni načrt, pri katerem sta obe fazi samostojni in kronološko neodvisni, se pojavlja $v$ treh primerih $(21,4 \%)$ in samo v enem primeru $(7,15 \%)$ se pojavljata pretvorni raziskovalni načrt, pri katerem so bili kvalitativni podatki evalvacije prevedenega vprašalnika kvantificirani (30), ter raziskovalni načrt $\mathrm{z}$ integracijo metod na različnih ravneh proučevanja, pri katerem so bili kvalitativni intervjuji in fokusne skupine izvedeni pri snovalcih politike, zdravstvenem osebju ter pri predstavnikih skupnosti, presečna kvantitativna raziskava pa na ravni posameznih gospodinjstev (46). V celoti integrirani raziskovalni načrt po tipologiji Teddlie in Tashakkori (1) med analiziranimi raziskavami ni bil prisoten. 
Tabela 3. Vrste raziskovalnih načrtov integracije metod $v$ analiziranih raziskavah*.

Table 3. Typologies of mixed methods research designs in analyzed studies.

\begin{tabular}{|l|l|l|l|l|}
\hline $\begin{array}{l}\text { Tipologija/Typology } \\
\text { Raziskava/Study }\end{array}$ & $\begin{array}{l}\text { Teddlie in } \\
\text { Tashakkori (1) }\end{array}$ & Morgan (26) & $\begin{array}{l}\text { Greene in drugi } \\
(27,28)\end{array}$ & $\begin{array}{l}\text { Creswell in Plano } \\
\text { Clark (25) }\end{array}$ \\
\hline Baker et al. (30) & pretvorni & QUAL-quan & triangulacija & triangulacija \\
\hline Hopson, Steiker (12) & zaporedni & QUAN-qual & komplementarnost & pojasnjevalni \\
\hline Smyth, Allen (37) & zaporedni & quan-QUAL & komplementarnost & pojasnjevalni \\
\hline Ploeg et al. (38) & zaporedni & qual-QUAN & komplementarnost & eksploratorni \\
\hline Hawkes et al. (39) & zaporedni & QUAN-qual & ekspanzija & pojasnjevalni \\
\hline Rivard et al. (41) & zaporedni & QUAN-qual & komplementarnost & pojasnjevalni \\
\hline Colarossi et al. (42) & sočasni & QUAN-qual & triangulacija & triangulacija \\
\hline Blakely et al. (43) & zaporedni & QUAL-quan & komplementarnost & eksploratorni \\
\hline Schreiber et al. (44) & zaporedni & QUAN-qual & komplementarnost & pojasnjevalni \\
\hline Durham et al. (45) & sočasni & qual-QUAN & triangulacija & triangulacija \\
\hline Schaetti et al. (46) & multilevel & QUAL-quan & ekspanzija & eksploratorni \\
\hline Sverker et al. (47) & zaporedni & QUAL-quan & komplementarnost & eksploratorni \\
\hline Levett-Jones et al. (48) & zaporedni & QUAN-qual & komplementarnost & pojasnjevalni \\
\hline Barnes et al. (15) & sočasni & quan-QUAL & triangulacija & triangulacija \\
\hline
\end{tabular}

*Pregledne sistematične študije in raziskave brez integracije metod $v$ empiričnem delu raziskave $v$ analizo niso bile uvrščene.

Po tipologiji Morgan (26) se pojavljajo vse štiri oblike raziskovalnih načrtov integracije metod glede na prioriteto in zaporedje izvedbe kvantitativnega in kvalitativnega dela $v$ raziskavi. Tipologiji nadaljevalne kvalitativne raziskave $v$ kvantitativni raziskavi (QUANqual) in nadaljevalne kvantitativne raziskave $v$ kvalitativni raziskavi (QUAL-quan) se pojavljata enakovredno, in sicer vsaka v petih primerih $(35,7 \%)$. Prva faza raziskave tako $v$ večini primerov $(71,4 \%)$ nastopa kot prioritetna ne glede na to, ali gre za kvantitativno ali kvalitativno fazo raziskave. $V$ manjšem deležu $(28,6 \%)$ se pojavlja prioritetna druga faza in tudi tukaj je enakovredno razmerje med tipologijama predhodne kvalitativne metode $v$ kvantitativni raziskavi (qual-QUAN) $(14,3 \%)$ in predhodne kvantitativne metode v kvalitativni raziskavi (quan-QUAL) (14,3\%). Ne glede na zaporedje raziskovalnih faz pa je razmerje med kvantitativnim kvalitativnim pristopom precej enakovredno, z nekoliko večjo prisotnostjo raziskav s prioritetnim kvantitativnim pristopom $(57,2 \%)$ v primerjavi s kvalitativnim (42,8\%).
Glede na namen uporabe integracije metod po tipologiji Greene $(27,28)$ so rezultati pokazali najpogostejšo uporabo komplementarnosti, ki temelji na predpostavki, da rezultati ene metode, kvantitativne ali kvalitativne, služijo za povečanje, poglobitev in za razširitev ugotovitev, pridobljenih $z$ drugo metodo. Komplementarni odnos med kvantitativnim in kvalitativnim delom se pojavlja $v$ osmih raziskavah $(57,1 \%)$. Hopson in Steiker (12) uporabita kvantitativne anketne vprašalnike za raziskovanje socialnodemografskih spremenljivk, prisotnosti uživanja drog in alkohola, stališč in pričakovanj do drog in alkohola ter spremenljivk šolskega okolja, v nadaljevanju po izvedbi kvantitativne raziskave izvedeta še fokusne skupine z namenom proučiti poglede študentov in učiteljev, ki ne morejo biti v celoti razumljeni skozi rezultate kvantitativnih anket. Zelo podobno sta tudi Smyth in Allen (37) v prvem delu izvedla manjšo kvantitativno anketno raziskavo o socialno-demografskih podatkih, samooceni duhovnosti, znanju in razumevanju izvajanja duhovne oskrbe $v$ klinični praksi ter o ovirah, s katerimi 
se medicinske sestre srečujejo pri tem. $V$ drugem delu je raziskava $z$ nestrukturiranimi fokusnimi skupinskimi intervjuji omogočila udeležencem, da so ustno pojasnili in razširili odgovore na anketni vprašalnik ter osvetlili svoje unikatne izkušnje. Raziskava Rivard s sodelavci (41) je šest mesecev enkrat tedensko zbirala kvantitativne podatke posredovalcev znanja o samoevalvaciji izvedbe dela v klinični praksi pediatrične fizikalne terapije. Sekundarna faza raziskave, ki je bila razvita na kvantitativnih rezultatih prve faze, je bila analiza polstrukturiranih kvalitativnih telefonskih intervjujev ob koncu izvedbe programa ter je imela pojasnjevalno naravo vpogleda $v$ doživljanje vloge posredovalca znanja in izkušenj z izvedbo. Schreiber s sodelavci (44) je proučeval učinkovitost programa na dokazih podprte prakse $v$ fizioterapiji, $v$ katerem je pred izvedbo programa in po šestih mesecih izvedbe $s$ kvantitativnim merskim instrumentom ugotavljal stališča in mnenja udeležencev do raziskovanja. Po izvedbi programa je bil vsak udeleženec še intervjuvan z namenom nadaljnje pojasnitve svojih stališč, znanja, izkušenj ter lastnih sprememb glede na dokazih podprte prakse. Na zelo podoben način je raziskovala pripadnost študentov do zdravstvene nege tudi avtorica Levett-Jones s sodelavci (48), ki je v prvem delu raziskave izvedla spletno anketno raziskavo pri 362 študentih, pri čemer je uporabila kot merski instrument ocenjevalno lestvico. Iz celotnega vzorca študentov, ki so izpolnili anketne vprašalnike, je sledil namenski izbor 18 študentov za izvedbo poglobljenih polstrukturiranih intervjujev. $V$ vseh predstavljenih raziskavah gre ob komplementarnem raziskovalnem načrtu $(27,28)$ tudi za pojasnjevalni raziskovalni načrt po tipologiji Creswell in Plano Clark (25), saj rezultati druge kvalitativne faze raziskave pojasnjujejo rezultate prve kvantitativne faze raziskave.

$\checkmark$ raziskavi Ploeg s sodelavci (38) pa gre za komplementarni $(27,28)$ in eksploratorni $(25)$ raziskovalni načrt integracije metod. Avtorji so raziskavo začeli s kvalitativnimi intervjuji na vzorcu 23 namensko izbranih predstavnikov zdravstvene nege. Zbrane kvalitativne podatke so obdelali in na osnovi dobljenih rezultatov razvili spremenljivke kvantitativne ankete, ki jo je izpolnilo 191 predstavnikov klinične prakse zdravstvene nege. Prav tako je tudi Blakely s sodelavci (43) raziskavo začel s 13 namensko izbranimi edukatorji zdravja, s katerimi so bili opravljeni polstrukturirani intervjuji. Na osnovi rezultatov prve kvalitativne faze raziskovalci oblikujejo spletni anketni vprašalnik, ki ga je izpolnilo 97 edukatorjev zdravja. Uporabo eksporativnega pristopa avtorji utemeljijo z ugotovitvijo, da področje didaktičnih iger $v$ zdravstvu ni poznano in raziskano, še posebej z vidika perspektive edukatorjev. Avtorica Sverker s sodelavci (47) je v prvi prioritetni raziskovalni fazi s kvalitativnimi intervjuji identificirala izkušnje, problematike in posledice obolenja s celiakijo na vsakodnevno pripravo hrane pri obolelih in njihovih svojcih. Raziskovalce je zanimalo doživljanje težav, ki jih imajo, ter vplivi na vsakodnevno življenje pri ženskah in moških. $Z$ namenom proučitve družbenega ozadja je bilo na istem vzorcu izvedeno še dopolnjujoče strukturirano kvantitativno anketiranje o načinu priprave hrane in prehranskih navadah.

Raziskovalni načrt triangulacije po tipologiji Green s sodelavci $(27,28)$ in Creswell in Plano Clark $(25)$ so uporabile štiri analizirane raziskave $(28,6 \%)$. Baker s sodelavci (30) je uporabil več kvalitativnih in kvantitativnih metod (kognitivni intervju, indeks vsebinske veljavnosti, Cronbachov test $\alpha$, t-test, Kolmogorov-Smirnov test) za testiranje ustreznosti šeststopenjske prevajalske metode za prevod anketnega instrumenta s področja zdravja. Avtorica Colarossi s sodelavci (42) je proučevala stališča, percepcijo ovir in mnenja o usposobljenosti zdravstvenega osebja v centrih za načrtovanje družine glede presejanja nasilja med intimnima partnerjema s kvantitativno (samoevalvacijski anketni vprašalniki) in kvalitativno (fokusne skupine) metodologijo sočasno na istem vzorcu. Namen uporabe integracije metod je bil iskati podobnosti in razlike med podatki kvantitativnega in kvalitativnega dela ter tako osvetliti različne vidike proučevanega fenomena. Durham s sodelavci (45) je osredinjenost fizioterapevtov na podajanje povratnih informacij med obravnavo proučeval z video snemanji obravnave, intervjuji s pacienti in fizioterapevti ter s kvantitativnim anketiranjem fizioterapevtov. Barnes s sodelavci (15) pa je učinke 12-tedenskega promocijskega programa zdravja na kakovost življenja in zadovoljstvo z življenjem pri odraslih z nizkimi prihodki proučeval $s$ standardiziranim kvantitativnim merskim instrumentom RAND SF-36, ki meri samooceno z zdravjem povezane kakovosti življenja, kvalitativnimi fokusnimi skupinami in kvalitativnimi vmesnimi evalvacijskimi poročili o napredku udeležencev. Vsa merjenja z navedenimi različnimi kvantitativnimi in kvalitativnimi tehnikami so bila pri tej raziskavi narejena na istem vzorcu.

Med analiziranimi raziskavami $z$ integracijo metod se kot raziskovalni načrt pojavlja še ekspanzija $(27,28)(14,3 \%)$. V raziskavi avtorice Hawkes s sodelavci (39) je bil raziskovalni problem razširjen na več raziskovalnih žarišč, in sicer na neposredno kvantitativno merjenje rezultatov izvajanja kliničnih smernic pri bolnikih in na kvalitativno raziskovanje razvoja in implementacije kliničnih smernic pri zdravstvenem osebju s polstrukturiranimi intervjuji. 
Schaetti s sodelavci (46) pa je raziskovanje uvedbe cepljenja proti koleri razširil na kvalitativno proučevanje mnenj snovalcev politike, zdravstvenega osebja in predstavnikov skupnosti ter na kvantitativno presečno raziskovanje determinant dejanskega prejemanja cepiva pri prebivalstvu.

Med analiziranimi raziskavami nismo zasledili raziskovalnih načrtov integracije metod, ki vključujejo iniciacijo oz. vpeljevanje paradoksov in nasprotij, ki vodijo $\mathrm{v}$ odpiranje novih pogledov in razumevanj $(27$, 28) ter ugnezden raziskovalni načrt, ki se najpogosteje uporablja pri eksperimentalnih raziskavah (25).

Vseh 25 analiziranih raziskav je potrdilo uspešnost uporabe integracije metod za raziskovanje raziskovalnih tematik v zdravstvu. Poudarjena pa je tudi potreba po zadostni premišljenosti pri načinu integracije kvantitativne in kvalitativne metodologije oziroma izbor ustreznega raziskovalnega načrta integracije metod glede na raziskovalni problem, upravičena uporaba kvalitativne raziskovalne faze ter zadostna upravičenost uporabe integracije metod glede na raziskovalni problem.

21 raziskav poudarja pomen nadaljnjega raziskovanja, in sicer v obliki priporočil za ponovitev raziskave na sorodnih ali kontrastnih populacijah (18), nadaljnje raziskovanje integracije metod $v$ spletnem raziskovanju (36), uvedbo integracije metod v postopku evalvacije kakovosti novega merskega instrumenta (30), nadaljnja raziskovanja uporabe integracije metod pri sistematični evalvaciji promocijskih zdravstvenih programov (12, $15,42,43)$ in razširitev možnosti uvedbe integracije metod v klinično prakso kot podpore pri razvoju na dokazih podprte prakse $(44,38,34,41,39,37,48$, 45). Mortenson in Oliffe (31) izpostavljata potrebo po nadaljnjem raziskovanju integracije metod na področju delovne terapije, Andrew in Halcomb (10) na področju patronažnega zdravstvenega varstva in Bushy (13) na področju raziskovanja zdravja in zdravstvene nege na podeželju. Potreba po integraciji kvantitativnih in kvalitativnih metod se zlasti izrazito kaže pri raziskovanju raziskovalnih tematik, ki so manj raziskane, kot je na primer promocija duševnega zdravja otrok (29), proučevanje duhovnosti in izvajanja duhovne oskrbe medicinskih sester (37), ugotavljanje nasilja med partnerjema $v$ centrih za načrtovanje družine (42), uporaba didaktičnih iger v zdravstvu (43), identificiranje dejavnikov, ki vplivajo na cepljenje proti koleri (46), problematike pri pripravi hrane obolelih s celikajo in njihovih svojcev (47) ter učinkovanje programov promocije zdravja na kakovost življenja in zadovoljstvo z življenjem pri skupinah z nižjim socialnoekonomskim statusom (15).

\section{RAZPRAVLJANJE}

Namen sistematične pregledne študije raziskav $z$ integracijo kvantitativne in kvalitativne metodologije na področju zdravstva, ki so bile objavljene v zadnjih petih letih, je bil ugotoviti tematska področja in raziskovalne tematike, vrste uporabljenih raziskovalnih načrtov, uspešnost uporabe in nadaljnja odprta raziskovalna vprašanja integracije metod v raziskavah v zdravstvu. Izsledki so pokazali, da ima integracija metod močno tradicijo $v$ raziskovanju na področju zdravstva, zlasti je prisotna $v$ zdravstveni negi in promociji zdravja, opazna pa je njena uporaba tudi $v$ fizioterapiji, delovni terapiji in v javnem zdravju. Vseh 25 raziskav je podprlo uporabo integracije metod pri raziskovanju tematik s področja zdravstva. Podobne ugotovitve so z metodo sistematičnega pregleda dozdajšnjih raziskav oblikovali tudi Plano Clark s sodelavci (24), Koller in Sinitsa (8) ter Small (49).

Palinkas s sodelavci (50) je opravil analizo 50 člankov $z$ integracijo metod $s$ področja mentalnega zdravja, ki so bili objavljeni v obdobju 2005-2009 v revijah $z$ recenzijo in dostopni $v$ bazi podatkov PubMed Central ter v 60 nacionalnih zdravstvenih inštitutih (CRISP). Izsledki so pokazali, da večina raziskav ni navedla posebnega razloga za uporabo integracije metod $v$ raziskavi in $74 \%$ analiziranih raziskav je dalo prioriteto kvantitativnemu raziskovalnemu pristopu. $\mathrm{V}$ naši raziskavi na vzorcu 25 prispevkov različnih področij zdravstva se je pokazalo razmerje med pristopoma kot enakovredno in kaže na večjo zastopanost tudi prioritetnega kvalitativnega pristopa $v$ raziskavah z integracijo metod na področju zdravstva. Avtorica Niglas (51), ki je z metaanalizo analizirala raziskovalni pristop $v 145$ raziskavah $\mathrm{z}$ integracijo metod na področju izobraževanja, je ugotovila, da je integracija metod največkrat uporabljena v kvalitativnih raziskavah z nekaterimi kvantitativnimi elementi (33\%), eksperimentih s kvalitativno komponento (29\%) in $\mathrm{v}$ kvantitativnih anketnih raziskavah $\mathrm{s}$ kvalitativno komponento (28\%). Podobno smo ugotovili tudi v naši raziskavi, $v$ kateri polovica analiziranih raziskav z integracijo metod temelji na kvantitativni raziskavi s kvalitativno komponento in polovica na kvalitativni raziskavi s kvantitativno komponento. Med $v$ analizo vključenimi študijami pa $v$ primerjavi $z$ raziskavo avtorice Niglas (51) ni bilo nobene eksperimentalne raziskave. Večina raziskav $z$ integracijo metod $v$ naši raziskavi je $v$ kvantitativnem delu temeljila na presečni anketni raziskavi, $v$ kvalitativnem delu pa na presečnih polstrukturiranih intervjujih ali fokusnih skupinah. Podobne izsledke je oblikoval tudi Bryman (52) na 
vzorcu vsebinske analize 232 raziskav z integracijo metod na področju družbenih ved (sociologija, psihologija, management in organizacija, geografija, medijske in kulturne študije), kjer so se na kvantitativni strani kot prioritetni pokazali strukturirani intervjuji in samoevalvacijski anketni vprašalniki v presečnih raziskavah, na kvalitativni strani pa semistrukturirani intervjuji v presečnih raziskavah.

$Z$ vidika postopka izvedbe kvantitativnega in kvalitativnega dela $v$ raziskavi $z$ integracijo metod je Collins s sodelavci (53) na vzorcu 121 raziskav $s$ področja zdravstva in družboslovja ugotovil, da je več ali $66,1 \%$ raziskovalnih načrtov integracije metod sočasnih in 33,9\% zaporednih. $V$ naši raziskavi, ki je vključevala raziskave samo s področja zdravstva, pa se je kot prevladujoč pokazal zaporedni način integracije kvantitativnega in kvalitativnega dela, saj je tak pristop uporabilo kar $64,3 \%$ analiziranih raziskav. Sočasni pristop integracije metod je uporabilo $21,4 \%$ raziskav, $\checkmark$ enem primeru sta se pojavila tudi pretvorni način kvantificiranja podatkov ter integracija kvantitativne in kvalitativne metodologije na več različnih ravneh raziskovanja (snovalci politike, prebivalstvo). Večjo prisotnost uporabe zaporednega načina integracije metod $\mathrm{v}$ primerjavi s sočasnim pristopom $\mathrm{v}$ raziskavah s področja zdravstva $(n=168)$ za obdobje 1999-2009 navaja tudi Östlund s sodelavci (9). Dobljeni izsledki so pozitivni, ker kažejo premik $v$ uporabi različnih načinov izvedbe kvantitativnega in kvalitativnega dela $v$ raziskovalni praksi zdravstvenih ved $v$ obdobju zadnjih petih let.

Pri analiziranju z vidika namena uporabe integracije metod glede na raziskovalni problem po klasifikaciji Greene in drugi $(27,28)$ smo v naši raziskavi ugotovili predvsem tri namene integracije metod: komplementarni/pojasnjevali/eksploratorni $(57,1 \%)$, triangulacijski $(28,6 \%)$ in ekspanzivni $(14,3 \%)$. Dobljeni izsledki so primerljivi z izsledki avtorja Bryman (52), ki prav tako kot najpogostejši namen uporabe integracije metod navaja komplementarnost $(44,8 \%)$, ekspanzijo $(31,5 \%)$ in triangulacijo (12,5\%). Podobno tudi Östlund s sodelavci (9) navaja triangulacijo in komplementarnost kot najpogostejša namena uporabe integracije metod $\mathrm{v}$ raziskavah $\mathrm{v}$ zdravstvu.

Naša sistematična pregledna raziskava je pokazala, da vse analizirane študije podpirajo uporabo integracije metod v raziskovanju na področju zdravstva ter omenjajo tematike in odprta raziskovalna vprašanja nadaljnjega metodološkega razvoja integracije metod, kot je na primer konceptualizacija integracije metod $v$ posameznih disciplinah zdravstvenih ved (npr. patronažno varstvo, delovna terapija, promocija zdravja), ki ima vsako svoje specifike raziskovalnih problemov in s tem tudi načinov integracije kvantitativnega in kvalitativnega dela $v$ isti raziskavi. Poudariti velja tudi ugotovitev, da kar osem analiziranih raziskav navaja priporočilo uvedbe integracije metod $v$ klinično prakso kot podpore pri razvoju na dokazih podprte prakse. Pri raziskavah $\mathrm{z}$ integracijo metod se odpirajo tudi vprašanja meril in standardov ocenjevanja in vrednotenja kakovosti raziskovanja z integracijo metod (28). Bryman, Becker in Sempik (14) predlagajo za presojanje kakovosti raziskave $z$ integracijo metod uporabo kombinacije tradicionalnih kvantitativnih in kvalitativnih raziskovalnih meril ter razvoj novih specializiranih raziskovalnih meril za ugotavljanje kakovosti specifik raziskav z integracijo metod. Med njimi poudarjajo, da je treba vključiti v presojanje ustreznost raziskovalnih vprašanj, transparentnost postopkov izvedbe raziskave, potrebo po integraciji ugotovitev in utemeljitev uporabe integracije metod $v$ raziskavi.

$\mathrm{Na}$ podlagi ugotovitev naše raziskave velja poudariti usmeritve za izvedbo integracije metod $v$ raziskovalni praksi zdravstvenih ved. Raziskave z integracijo metod naj se uporabijo predvsem pri proučevanju raziskovalnih problemov in tematik, ki so kompleksne narave in o katerih je $v$ domačem in mednarodnem prostoru malo poznanega in raziskanega, kot so na primer problematike specifičnih subpopulacij ali evalvacije novih programov promocije zdravja. Odločitev za uporabo integracije kvantitativne in kvalitativne metodologije pa tudi izbor določenega raziskovalnega načrta integracije metod je treba upravičiti, in sicer z vidika, kako bo integracija metod prispevala $\mathrm{k}$ odgovorom na postavljena raziskovalna vprašanja raziskave. Če je na raziskovalna vprašanja mogoče odgovoriti samo s kvantitativno ali samo kvalitativno metodologijo, uporaba integracije metod $v$ raziskavi ni upravičena. Glede na dobljene ugotovitve se integracija metod kaže kot zlasti dobrodošla za proučevanje raziskovalnih problemov na področju zdravstvene nege in promocije zdravja, mogoče pa jo je uporabiti pri raziskovanju vseh zdravstvenih disciplin. Najznačilnejša izvedba integracije metod je zaporedna izvedba kvantitativne in kvalitativne faze s komplementarnim odnosom, kar pomeni, da so ugotovitve prve raziskovalne faze predpogoj za zasnovo in izvedbo druge raziskovalne faze, integrirani rezultati kvantitativnega in kvalitativnega dela skupaj pa predstavljajo celoto in odgovarjajo na raziskovalna vprašanja raziskave.

Pri posploševanju predstavljenih ugotovitev izvedene sistematične pregledne študije na vzorcu 25 raziskav $z$ integracijo metod $v$ zdravstvu je potrebno biti pozoren 
tudi na določene omejitve raziskave. Raziskava temelji na analiziranih prispevkih, ki so bili pridobljeni s pomočjo štirih spletnih iskalnikov elektronskih baz podatkov objavljenih prispevkov: WebSurvey Methodology, CINAHL, MEDLINE in PubMed. Merila izbora iskalnikov so bila znanstveno področje, ki ga pokrivajo (zdravstvo, raziskovalna metodologija), možnost naprednega iskanja in s tem opredelitve vključitvenih meril, prosta dostopnost ter primerljivost $\mathrm{s}$ sorodnimi raziskavami $(9,50)$. Navedeni izbor pa predstavlja tudi določene omejitve, saj $v$ iskanje niso bile vključene tudi druge baze podatkov s področja zdravstva (npr. PsycINFO), baza podatkov Web of Science in druge, največkrat zaradi licenčno omejenega dostopa. Prav tako v iskanje ni bil vključen pregled elektronskih objav po posameznih specializiranih revijah. Razlog so bile manjše zmožnosti funkcij iskalnikov (osnovno iskanje) na spletnih straneh revij, ki niso omogočale poenotenega iskanja z iskalniki elektronskih baz podatkov in prav tako tudi ne opredelitve vključitvenih meril (npr. obdobje objav 2006-2011). Zlasti je pričakovati, da bi bile za raziskovanje zanimive objave $v$ interdisciplinarni reviji $s$ področja integracije metod "The Journal of Mixed Method Research «, katere objavljeni prispevki niso bili vključeni v baze podatkov, ki so bile proučevane $v$ naši raziskavi. Zasnovati metodološki pristop, ki bo omogočil poenoteno iskanje in analizo prispevkov tudi v spletnih iskalnikih elektronskih baz posameznih revij ter s tem prispeval k popolnejšim ugotovitvam proučevanega raziskovalnega problema, ostaja izziv za prihodnja raziskovanja.

Kot omejitev raziskave velja izpostaviti tudi način iskanja po ključnih besedah $v$ izbranih iskalnikih. Avtorica Gorecki s sodelavci (54) je evalvirala učinkovitost petih elektronskih iskalnikov baz podatkov objavljenih prispevkov na poljubno izbrano temo »vpliv razjede zaradi pritiska na kakovost življenja«. Avtorji so ugotovili, da iskalniki elektronskih baz podatkov pri iskanju raziskav z integracijo metod pokažejo predvsem zadetke s ključnimi besedami in predmetnimi oznakami, ki dajejo prednost kvantitativni metodologiji. Iskalniki niso identificirali prisotnosti kvalitativnih podatkov $v$ raziskavah $z$ integracijo metod. Največ ustreznih zadetkov je dal iskalnik CINAHL, vendar tudi ta ni odkril kvalitativnih komponent proučevane tematike $\mathrm{v}$ raziskavah $\mathrm{z}$ integracijo metod. Zelo dobre rezultate je pokazal tudi iskalnik MEDLINE, ki je boljše odkril raziskave $z$ integracijo metod. Avtorji so poudarili, da omogoča najboljše zadetke iskanja prispevkov kombinacija več različnih iskalnikov. Naša raziskava je glede na prioriteto uporabljenega pristopa pokazala precej enakovredno razmerje med prioritetno kvantitativno in prioritetno kvalitativno metodologijo $\mathrm{v}$ raziskavah z integracijo metod, kar kaže na ustrezno občutljivost za iskanje tudi kvalitativnih podatkov $\mathrm{v}$ raziskavah z integracijo metod. Navedeno velja pripisati izboru možnosti iskanja po besedilu člankov in ne samo po ključnih besedah, iskanje po sorodnih besedah ter kombinaciji iskanja $v$ štirih različnih iskalnikih. Pa vendarle ne gre prezreti ugotovitev, da so se $v$ izbor 25 raziskav uvrstile tudi štiri raziskave $(32,33,35,36)$, ki pri svojem empiričnem raziskovanju niso uporabile integracije metod. Pri teh raziskavah je šlo za različne načine zbiranja podatkov [angl. mixed modes], ki so temeljile na večmetodnem kvantitativnem pristopu. Navedeno pripisujemo nedoslednosti $v$ uporabi terminologije integracije metod in tudi vključeni možnosti iskanja po sorodnih besedah. Dobljeni izsledki tako kažejo, da uporabljeni iskalniki elektronskih baz podatkov pri iskanju po ključnih besedah »mixed methods « pokažejo tudi zadetke s ključnimi besedami »multimethod «. Ugotovitve so skladne z navedbami Teddlie in Tashakkori (1), ki opozarjata na pogost pojav terminološke zamenjave termina integracija metod $z$ večmetodnim pristopom, ki lahko vključuje tudi dve ali več samo kvantitativnih metod, kar se je pokazalo tudi na primeru štirih raziskav $v$ naši študiji.

\section{ZAKLJUČEK}

Dobljene ugotovitve sistematične pregledne raziskave potrjujejo uporabnost in metodološko ustreznost uporabe integracije metod $v$ raziskavah $v$ zdravstvu, in sicer zlasti za kompleksnejše in manj raziskane problematike. Integracija kvantitativne in kvalitativne metodologije, ki izhaja iz raziskovalnih vprašanj raziskave, omogoča celostni vpogled in s tem bolj poglobljeno proučitev raziskovalnega problema; tako upravičeno predstavlja tretjo raziskovalno paradigmo v znanosti. Posebno pozornost je v prihodnje treba posvetiti razvoju meril in standardov ocenjevanja kakovosti izvedenih raziskav $\mathrm{z}$ integracijo metod ter uvedbi integracije metod $v$ klinično prakso kot podpore pri razvoju na dokazih podprte prakse.

\section{Zahvala}

Avtorica se $z$ vsem spoštovanjem zahvaljuje prof. dr. Anuški Ferligoj s Fakultete za družbene vede Univerze v Ljubljani za vso podporo pri izvedbi te raziskave in dragocene nasvete pri pisanju prispevka ter prof. dr. Katrin Niglas iz Tallinn University v Estoniji za oblikovanje izhodiščne zamisli za izvedbo te raziskave. 


\section{Literatura}

1. Teddlie C, Tashakkori A. Foundations of mixed methods research: integrating quantitative and qualitative approaches in the social and behavioral sciences. London: Sage Publications, 2009.

2. Teddlie $\mathrm{C}$, Tashakkori A. Major issues and controversies in the use in mixed methods in the social and behavioral sciences. In: Tashakkori A, Teddlie C, eds. Handbook of mixed methods in social and behavioral research. Thousand Oaks: Sage Publications, 2003: 3-50.

3. Gorard S, Taylor C. Combining methods in educational and social research. Buckingham: Open University Press, 2004.

4. Johnson RB, Onwuegbuzie A. Mixed methods research: a research paradigm whose time has come. Educ Res 2004; 33: 14-26.

5. Niglas K. The multidimensional model of research methodology: an integrated set of continua. In: Tashakkori A, Teddlie C, eds. Handbook of mixed metods research. 2nd ed. London: Sage Publications, 2010: 215-236.

6. Johnson RB, Onwuegbuzie AJ, Turner LA. Toward a definition of mixed methods research. J Mix Methods Res 2007; 1: 112-133.

7. Lobe B. Združevanje kvalitativnih kvantitativnih metod - stara praksa v novi preobleki? Družboslovne razprave 2006; 22: 55-73.

8. Koller M, Sinitsa E. Mixed methods in online research. In: Conceptualisation and future research agenda - General Online Research Conference; 2009 Apr 6-8, Vienna, Austria. Vienna: University of Vienna, 2009.

9. Östlund U, Kidd L, Wengström Y, Rowa-Dewar N. Combining qualitative and quantitative research within mixed method research designs: a methodological review. Int J Nurs Stud 2011; 48: 369-383.

10. Andrew S, Halcomb EJ. Mixed methods research is an effective method of enquiry for community health research. Contemp Nurse 2006; 23: 145-153.

11. Curtis RS, Rabren K, Reilly A. Post-school outcomes of students with disabilities: a quantitative and qualitative analysis. J Vocat Rehabil 2009; 30: 31-48.

12. Hopson LM, Steiker LKH. Methodology for evaluating an adaptation of evidence-based drug abuse prevention in alternative schools. Child Sch 2008; 30: 116-127.

13. Bushy A. Conducting culturally competent rural nursing research. Annu Rev Nurs Res 2008; 26: 221-236.

14. Bryman A, Becker S, Sempik J. Quality criteria for quantitative, qualitative and mixed methods research: a view from social policy. Int J Soc Res Methodol 2008; 11: 261-276.

15. Barnes M, Bigari K, Culler T, Gregory H, Hamilton J, Krawczyk S, Earley D, Herlache E. Healthy lifestyles through an Adaptive Living Program: a pilot study. Occup Ther Int 2008; 15: 269-283.

16. Zurc J. Mixed methods: backgrounds, findings and challenges: a systematic review. In: Minimizing and handling non-response in sample surveys - quantitative methods in the social sciences 2 , Seminar;2011Dec8-9, Leuven,Belgija. Leuven:LeuvenBiostatistics and statistical Bioinformatics Centre, 2011.

17. McMorris BJ, Petrie RS, Catalano RF, Fleming CB, Haggerty $\mathrm{KP}$, Abbott RD. Use of web and in-person survey modes to gather data from young adults on sex and drug use: an evaluation of cost, time, and survey error based on a randomized mixed-mode design. Eval Rev 2009; 33: 138-158.

18. Revilla M. Quality in unimode and mixed-mode designs: a multitrait-multimethod approach. Surv Res Methods 2010; 4: 151-164.

19. Millar MM, Dillman DA. Improving response to web and mixedmode surveys. Public Opin Q 2011; 75: 249-269.
20. Gigliotti LM. Comparison of an internet versus mail survey: a case study. Human Dimensions Wildlife 2011; 16: 55-62.

21. Lobe B, Vehovar V. Towards a flexible online mixed method design with a feedback loop. Qual Quant 2009; 43: 585-597.

22. Deutskens E, de Ruyter K, Wetzels M. An assessment of equivalence between online and mail surveys in service research. J Service Res 2006; 8: 346-355.

23. Bayart $\mathrm{C}$, Bonnel $\mathrm{P}$. The mixing of survey modes: application to Laon web and face to face household travel survey - WAPOR 62nd Annual Conference; 2009 Sep 11-13, Lausanne, Switzerland.

24. Plano Clark VL, Huddleston-Casas CA, Churchill SL, O,Neil Green D, Garrett AL. Mixed methods approaches in family science research. J Fam Issues 2008; 29: 1543-1566.

25. Creswell JW, Plano Clark VL. Choosing a mixed methods design. In: Creswell JW, Plano Clark VL, eds. Designing and conducting mixed methods research. Thousand Oaks: Sage Publications, 2007: 58-88.

26. Morgan DL. Practical strategies for combining qualitative and quantitative methods: applications to health research. Qual Health Res 1998; 8: 362-376.

27. Greene JC, Caracelli VJ, Graham WF. Toward a conceptual framework for mixed-method evaluation designs. Educ Eval Policy Anal 1989; 11: 255-274.

28. Greene JC. Mixed methods in social inquiry. San Francisco: Jossey-Bass, 2007.

29. Landsverk J, Brown CH, Rolls Reutz J, Palinkas L, Horwitz SM. Design elements in implementation research: a structured review of child welfare and child mental health studies. Adm Policy Ment Health 2011; 38: 54-63.

30. Baker DL, Melnikow J, Ying Ly M, Shoultz J, Niederhauser V, Diaz-Escamilla R. Translation of health surveys using mixed methods. J Nurs Scholarsh 2010; 42: 430-438.

31. Mortenson WB, Oliffe JL. Mixed methods research in occupational therapy: a survey and critique. OTJR 2009; 29: 14-23.

32. Dunning K, LeMasters GK. Optimum survey methods when interviewing employed women. Am J Ind Med 2009; 52: 105-112.

33. Nigg CR, Motl RW, Wong KT, Yoda LU, McCurdy DK, Paxton $\mathrm{R}$, et al. Impact of mixed survey modes on physical activity and fruit/vegetable consumption: a longitudinal study. Surv Res Methods 2009; 3: 81-90.

34. Vatne S, Fagermoen MS. Event-oriented data integration: a qualitative strategy in studying professional practice. Res Theory Nurs Pract 2008; 22: 38-55.

35. Joubert DJ, Lee TP. Empowering your institution through assessment. J Med Libr Assoc 2007; 95: 46-53.

36. McCabe SE, Diez A, Boyd CJ, Nelson TF, Weitzman ER. Comparing web and mail responses in a mixed mode survey in college alcohol use research. Addict Behav 2006; 31: 16191627.

37. Smyth $\mathrm{T}$, Allen S. Nurses, experiences assessing the spirituality of terminally ill patients in acute clinical practice. Int $\mathrm{J}$ Palliat Nurs 2011; 17: 337-343.

38. Ploeg J, Skelly J, Rowan M, Edwards N, Davies B, Grinspun $D$, Bajnok I, Downey A. The role of nursing best practice champions in diffusing practice guidelines: a mixed methods study. Worldviewa Evid Based Nurs 2010; 7: 238-251.

39. Hawkes C, Foxcroft DR, Yerrell P. Clinical guideline for nurse-led early extubation after coronary artery bypass: an evaluation. $J$ Adv Nurs 2010; 66: 2038-2049.

40. Beckwith, Dickinson A, Kendall S. Exploring understanding of the term nursing assessment: a mixed method review of the literature. Worldviews Evid Based Nurs 2010; 7: 98-110.

41. Rivard LM, Russell DJ, Roxborough L, Ketelaar M, Bartlett 
DJ, Rosenbaum P. Promoting the use of measurement tools in practice: a mixed-methods study of the activities and experiences of physical therapist knowledge brokers. Phys Ther 2010; 90: 1580-1590.

42. Colarossi L, Breitbart V, Betancourt G. Barriers to screening for intimate partner violence: a mixed-methods study of providers in family planning clinics. Perspect Sex Reprod Health 2010; 42: 236-243.

43. Blakely G, Skirton H, Cooper S, Allum P, Nelmes P. Use of educational games in the health professions: a mixed-methods study of educators' perspectives in the UK. Nurs Health Sci 2010; 12: 27-32.

44. Schreiber J, Downey P, Traister J. Academic program support for evidence-based practice: a mixed-methods investigation. $\mathrm{J}$ Phys Ther Educ 2009; 23: 36-43.

45. Durham K, Van Vliet PM, Badger F, Sackley C. Use of information feedback and attentional focus of feedback in treating the person with a hemiplegic arm. Physiother Res Int 2009; 14: 77-90.

46. Schaetti C, Hutubessy R, Ali SM, Pach A, Weiss MG, Chaignat CL, Khatib AM. Oral cholera vaccine use in Zanzibar: socioeconomic and behavioural features affecting demand and acceptance. BMC Public Health 2009; 9: 99.
47. Sverker A, Östlund G, Hallert C, Hensing G. «l lose all these hours...: : exploring gender and consequences of dilemmas experienced in everyday life with coeliac disease. Scand $\mathrm{J}$ Caring Sci 2009; 23: 342-352.

48. Levett-Jones T, Lathlean J, Higgins I, McMillan M. The duration of clinical placements: a key influence on nursing students, experience of belongingness. Aust J Adv Nurs 2008; 26: 8-16.

49. Small ML. How to conduct a mixed methods study: recent trends in a rapidly growing literature. Annu Rev Sociol 2011; 37: 57-86.

50. Palinkas LA, Horwitz SM, Chamberlain P, Hurlburt MS, Landsverk J. Mixed-methods designs in mental health services research: a review. Psychiatr Serv 2011; 62: 255-263.

51. Niglas K. How the novice researcher can make sense of mixed methods design. Int J Multiple Res Approach 2009; 3: 34-46.

52. Bryman A. Integrating quantitative and qualitative research: how is it done? Qual Res 2006; 6: 97-113.

53. Collins KMT, Onwuegbuzie AJ, Jiao QG. A mixed methods investigation of mixed methods sampling designs in social and health science research. J Mix Methods Res 2007; 1: 267-294.

54. Gorecki CA, Brown JM, Briggs M, Nixon J. Evaluation of five search strategies in retrieving qualitative patient-reported electronic data on the impact of pressure ulcers on quality of life. J Adv Nurs 2010; 66: 645-652. 